\title{
INFLUENCE OF ALLOYING ELEMENTS ON THE MICROSTRUCTURE OF NEW COBALT MATRIX SUPERALLOYS REINFORCED WITH PHASE - $\mathrm{L1}_{2}$
}

\author{
WPEYW PIERWIASTKÓW STOPOWYCH NA MIKROSTRUKTURĘ NOWYCH \\ NADSTOPÓW NA OSNOWIE KOBALTU UMACNIANYCH FAZĄ - L1 ${ }_{2}$
}

The article presents selected results of research on the primary structure of a new generation of cobalt-based Co-20Ni-10Al-5Mo$2 \mathrm{Nb}$ superalloys. Research on this group of materials was started in 2006 by J. Sato. These materials are anticipated to be able to replace nickel-based superalloys in the future due to their superior elevated temperature properties compared to the nickel-based superalloys. Today, $\gamma^{\prime}$ nickel-based superalloys are still unrivalled in aerospace applications, however, cobalt-based superalloys are a response to their existing limitations, which do not allow the current pace of aircraft engine development to be maintained.

Keywords: Co20Ni10Al5Mo2Nb, casting, primary microstructure, segregation, dendrites
W pracy przedstawiono wybrane wyniki badań nad pierwotna struktura nowej generacji nadstopów na osnowie kobaltu typu Co-20Ni-10Al-5Mo-2Nb. Badania nad ta grupa materiatów rozpocząt w 2006 roku J. Sato. Przewiduje sie, że materiaty te $w$ przyszłości moga zastapić nadstopy na osnowie niklu ze względu na ich doskonate właściwości $w$ podwyższonej temperaturze $w$ porównaniu z nadstopami na osnowie niklu. Obecnie nadstopy na osnowie niklu wzmacniane faza $\gamma$ ' sa nadal bezkonkurencyjne w zastosowaniach lotniczych, jednak nadstopy na bazie kobaltu sa odpowiedzia na ich istniejace ograniczenia, które nie pozwalaja na utrzymanie obecnego tempa rozwoju silników lotniczych.

Stowa kluczowe: Co20Ni10Al5Mo2Nb, odlewanie, pierwotna mikrostruktura, segregacja, dendryty

\section{INTRODUCTION}

Superalloys, also known as high-performance alloys, are metallic materials with unique physical and chemical properties, especially at a high temperature. Compared to other metallic materials, superalloys have high and stable mechanical properties and high resistance to the aggressive environment at high operating temperatures, i.e. they belong to the group of heat-resistant alloys. It is assumed that superalloys may be used at a temperature above approx. $810^{\circ} \mathrm{C}(1500 \mathrm{~F})[1]$.

Cobalt alloys, compared to other (nickel-based) superalloys, belonging to the group of refractory materials, i.e. intended for long-term operation, have unique properties, in particular [2]:

a) they show higher resistance to high-temperature corrosion,

b) they show higher resistance to thermal fatigue and abrasion resistance,

c) they have a higher melting point,

d) they are characterised by a high coefficient of thermal conductivity with a low coefficient of linear expansion,

e) they are characterised by a mild decrease in mechanical properties with increasing temperature (e.g. creep resistance), f) they show high stability during operation at low stresses and high temperature.

In 1971, Charles S. Lee [3] found that two-phase alloys in a three-component system, analogous to those in nickel superalloys, consist of a matrix with an RSC $(\gamma)$ lattice reinforced with coherent, ordered $\mathrm{L}_{2}\left(\gamma^{\prime}\right)$ precipitates. In 2006, J. Sato [4] showed that the intermetallic $\gamma^{\prime}-\left(\mathrm{L}_{2}\right)$ occurs in the structure of Co-Al-W superalloys.

This development turned out to be ground-breaking and initiated the creation of a new group of high-temperature superalloys, which made it possible to increase the maximum operating temperature of gas turbine engines. This made the new cobalt superalloys interesting in terms of applications in highly loaded components operating at elevated temperatures, such as turbine blades, discs, combustion chamber components and jet engine nozzles [5].

The development of a new group of precipitation-hardened cobalt-based superalloys made it possible to obtain a superalloy with a two-phase $\gamma / \gamma$ ' structure with satisfactory properties at high temperature, with a structure similar to that found in nickel-based superalloys.

Many research teams from around the world have undertaken in-depth research on this group of materials [2, 6-12]. The first research team was a group from India, 
i.e. Department of Materials Engineering, Indian Institute of Science, Bangalore 560012, India, under the leadership of S.K. Makineni with K. Chattopadhyay as the corresponding author [6]. In 2015, this group published the first article on a cobalt-based superalloy with the following composition: Co-10Al-5Mo-2Nb [2]. They presented the first results of research on the microstructure of cobalt-based superalloys without tungsten. The main disadvantage of cobalt-based Co-Al-W alloys is high density (from approximately 9.3 to $10.5 \mathrm{~g} / \mathrm{cm}^{3}$ ) compared to nickel-based superalloys (from approximately 7.9 to $8.5 \mathrm{~g} / \mathrm{cm}^{3}$ ) [3]. At the same time, the presence of tungsten makes it difficult to homogenise cast Co-Al-W alloys. The described new $\gamma-\gamma$ ' cobalt matrix superalloy, which does not contain Co-10Al-5Mo-2Nb tungsten, has a much lower density and shows a high yield strength, compared to other cobalt-based superalloys, including Co-Al-W. A two-phase structure containing cuboid precipitates of a coherent $\gamma$ '-Co(Ni) $)_{3}(\mathrm{Al}, \mathrm{Mo}, \mathrm{Nb})$ and $\gamma^{\prime}-\mathrm{Co}_{3}(\mathrm{Al}, \mathrm{Mo}$, Ta) phase was obtained in these superalloys. The density of the alloys with the addition of niobium was 8.25-8.35 $\mathrm{g} / \mathrm{cm}^{3}$, which is a significantly lower value than in the case of the Co-7Al-7W alloy with a density of $9.2 \mathrm{~g} / \mathrm{cm}^{3}$. Also, yield strength at room temperature related to the density of the new type of alloys was definitely more favourable (86 compared to $79 \mathrm{MPa} /\left(\mathrm{g} \cdot \mathrm{cm}^{-3}\right)$, respectively), and the temperature of the solvus of the $\gamma$ ' phase was higher [3].

Another article [7] of the same research group was based on adding nickel to the Co-10Al-5Mo-2Nb alloy (from 1 to $30 \%$, respectively) in order to increase the solvus temperature (from $866^{\circ} \mathrm{C}$ to above $950^{\circ} \mathrm{C}$ ). Heat treatment (ageing at $800^{\circ} \mathrm{C}$ for $5 \mathrm{~h}$ ) made it possible to create the identical $\gamma-\gamma$ microstructure as that of nickel-based superalloys [6-7]. In this way, it was presented how the introduction of nickel addition and increasing its content in the alloy to $30 \%$ influences the essential properties of the Co-xNi-10Al-5Mo$2 \mathrm{Nb}$ alloy. It was also found that tungsten-free alloys have higher strength properties (yield strength) both at room temperature and elevated temperature (over $800^{\circ} \mathrm{C}$ ) compared to the Co-9Al-9.8W alloy. The addition of $30 \% \mathrm{Ni}$ caused an increase in the solvus temperature to $990^{\circ} \mathrm{C}$ and an increase in the $\gamma$ ' phase volume fraction from 54\% to $76 \%$, which makes these alloys suitable for use in components operating at high temperatures [4, 13].

The aim of the study was to define the characteristic components of the microstructure of the cobalt-based superalloy, i.e. Co-Ni-Al-Mo-Nb, which is a reference material for research on the modification of its chemical composition, resulting in changes in its structure and properties.

\section{MATERIAL FOR TESTING}

The material for testing was a Co20Ni10A15Mo2Nb alloy. It was obtained in the process of casting into a $\varphi 20 \times 100 \mathrm{~mm}$ bar (the shape of the cast is shown in Fig. 1). The chemical composition of the cast component is presented in Table 1.

Table 1. Chemical composition of the Co-20Ni-10Al-5Mo-2Nb superalloy

Tabela 1. Skład chemiczny nadstopu Co-20Ni-10Al-5Mo-2Nb

\begin{tabular}{|c|c|c|c|c|c|}
\hline Element & Ni & Al & Mo & Nb & Co \\
\hline at \% & 20.5 & 9.8 & 5.2 & 2.4 & rest \\
\hline wt \% & 20.6 & 4.5 & 8.5 & 3.8 & rest \\
\hline
\end{tabular}
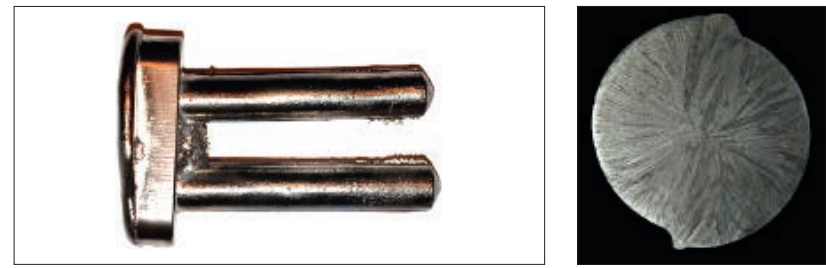

Fig. 1. Test material from cobalt Co-20Ni-10Al-5Mo-2Nb superalloy: a) superalloy cast, b) cross-section through the cast bar

Rys. 1.Materiał do badań z nadstopu kobaltu Co-20Ni-10Al-5Mo-2Nb: a) widok odlewu nadstopu, b) przekrój poprzeczny przez odlany pręt

\section{METHODOLOGY}

The program provided for carrying out a structure examination. The observation of the tested material was carried out on metallographic microsections. The metallographic microsections obtained from cross-sections taken from the tested bars were ground and mechanically polished, and the etched electrochemically (reagent $25 \mathrm{ml} \mathrm{H} \mathrm{H}_{2} \mathrm{O}, 50 \mathrm{ml}$ $\mathrm{HCl}, 15 \mathrm{~g} \mathrm{FeCl}_{3}$ and $3 \mathrm{~g} \mathrm{CuCl} \cdot \mathrm{NH}_{4} \mathrm{Cl} \cdot 2 \mathrm{H}_{2} \mathrm{O}$ ). Microstructure studies were performed using a Nicon Eclipse 200MA light microscope (LM) and an FEI Inspect F scanning electron microscope (SEM). The results of the structure analysis with a greater level of detail and the phase identification of the matrix of the tested alloy were confirmed by the results obtained with the use of an FEI TITAN scanning transmission electron microscope (S/TEM). In addition, a detailed microanalysis of the chemical composition of the precipitates occurring in the microstructure of the tested alloy was performed using an EDX detector which analyses chemical composition in micro-areas. The detector in the form of an attachment was part of the scanning and scanning transmission electron microscope.

\section{TEST RESULTS}

After casting, the Co-20Ni-10Al-5Mo-2Nb alloy is characterised by austenitic microstructure of a cobalt solid solution. The microstructure of the alloy as observed using a light microscope (LM) is shown in Fig. 2. The grain distribution from the sample's surface toward the axis was revealed in the material structure. The structure shows a zone of 'frozen' crystals on the surface of the material, elongated crystals (which are the least beneficial) and equiaxed crystals.

Fig. 3 shows the microstructures obtained using a scanning microscope with marked locations for the analysis of the chemical composition of the micro-areas including the matrix and precipitate. The results are shown in the table below.

These studies showed that the solid solution of the alloy contained cobalt and nickel, which dominate in the area of interdendritic precipitates. Clusters with a high concentration of niobium were observed on the map showing the distribution of this element. An area rich in niobium and molybdenum is visible around these precipitates. A detailed distribution of elements in these precipitates is shown in Fig. 4 on maps obtained with a scanning transmission microscope on a selected example of such a precipitate.

The analysis of the test results with the use of SEM and S/ TEM microscopes shows that the alloy is made of a solid Co solution as a matrix with the A1 structure, which was con- 

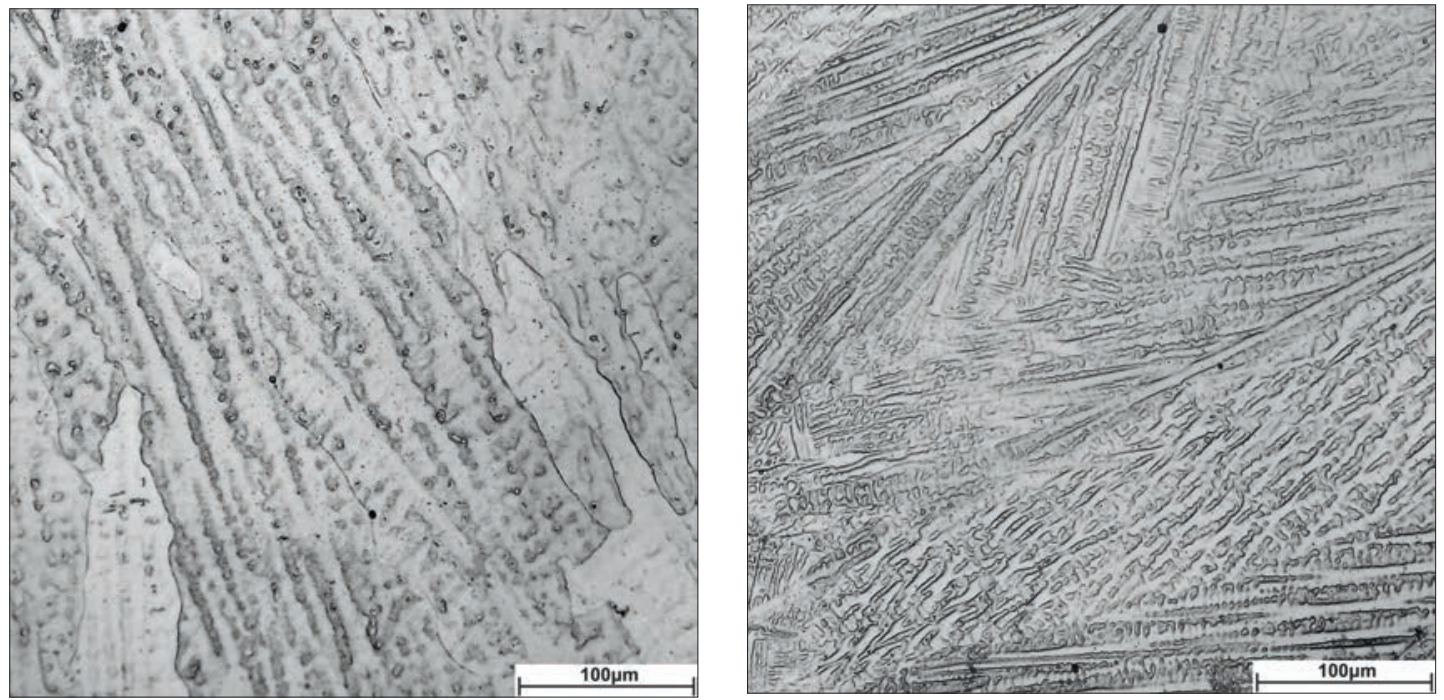

Fig. 2. Primary microstructure of cobalt-based Co-20Ni-10Al-5Mo-2Nb superalloy (LM)

Rys. 2. Mikrostruktura pierwotna nadstopu na osnowie kobaltu typu: Co-20Ni-10Al-5Mo-2Nb (LM)
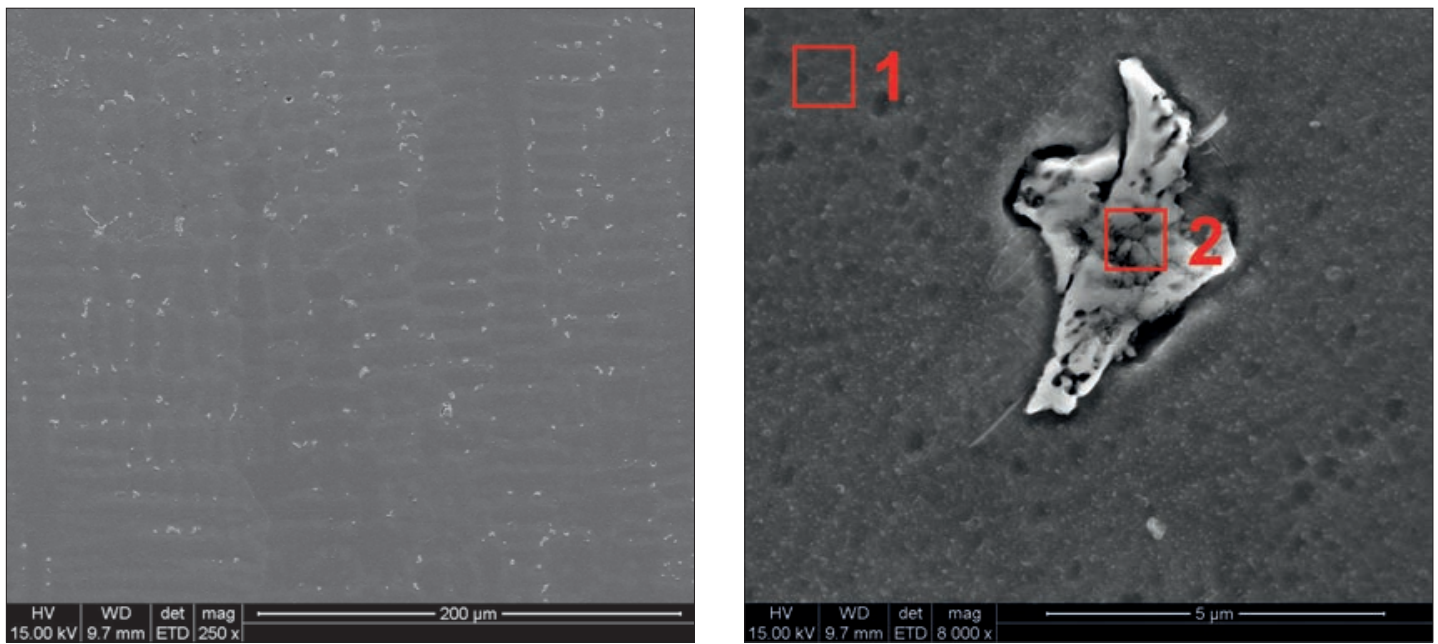

\begin{tabular}{|c|c|c|}
\hline \multirow{2}{*}{ Element } & \multicolumn{2}{|c|}{ Wt [\%] } \\
\cline { 2 - 3 } & Matrix (1) & Precipitate (2) \\
\hline $\mathrm{Al}$ & 4.2 & 2.6 \\
\hline $\mathrm{Nb}$ & 8.9 & 23.0 \\
\hline $\mathrm{Mo}$ & 9.8 & 10.8 \\
\hline $\mathrm{Co}$ & 57.5 & 48.4 \\
\hline $\mathrm{Ni}$ & 19.7 & 15.2 \\
\hline
\end{tabular}

Fig. 3. Primary microstructure of cobalt-based Co-20Ni-10Al-5Mo-2Nb superalloy (SEM). The table presents the results of the micro-analysis of chemical composition (EDX) for the marked areas

Rys. 3. Mikrostruktura pierwotna nadstopu na osnowie kobaltu typu Co-20Ni-10Al-5Mo-2Nb (SEM). W tabeli zestawiono wyniki mikroanalizy składu chemicznego (EDX) dla oznaczonych obszarów
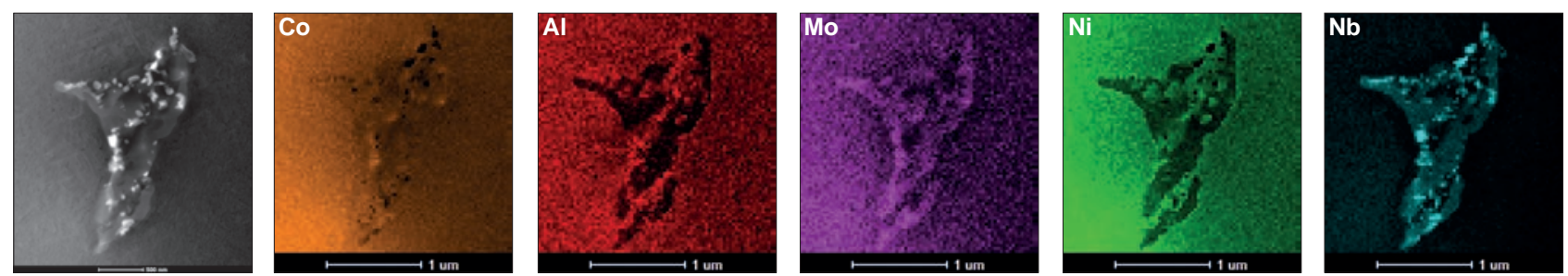

Fig. 4. Distribution of selected elements in the area of primary precipitation of the tested Co-20Ni-10Al-5Mo-2Nb superalloy (S/TEM) Rys. 4. Rozkład wybranych pierwiastków w obszarze wydzielenia pierwotnego badanego nadstopu Co-20Ni-10Al-5Mo-2Nb (S/TEM) 

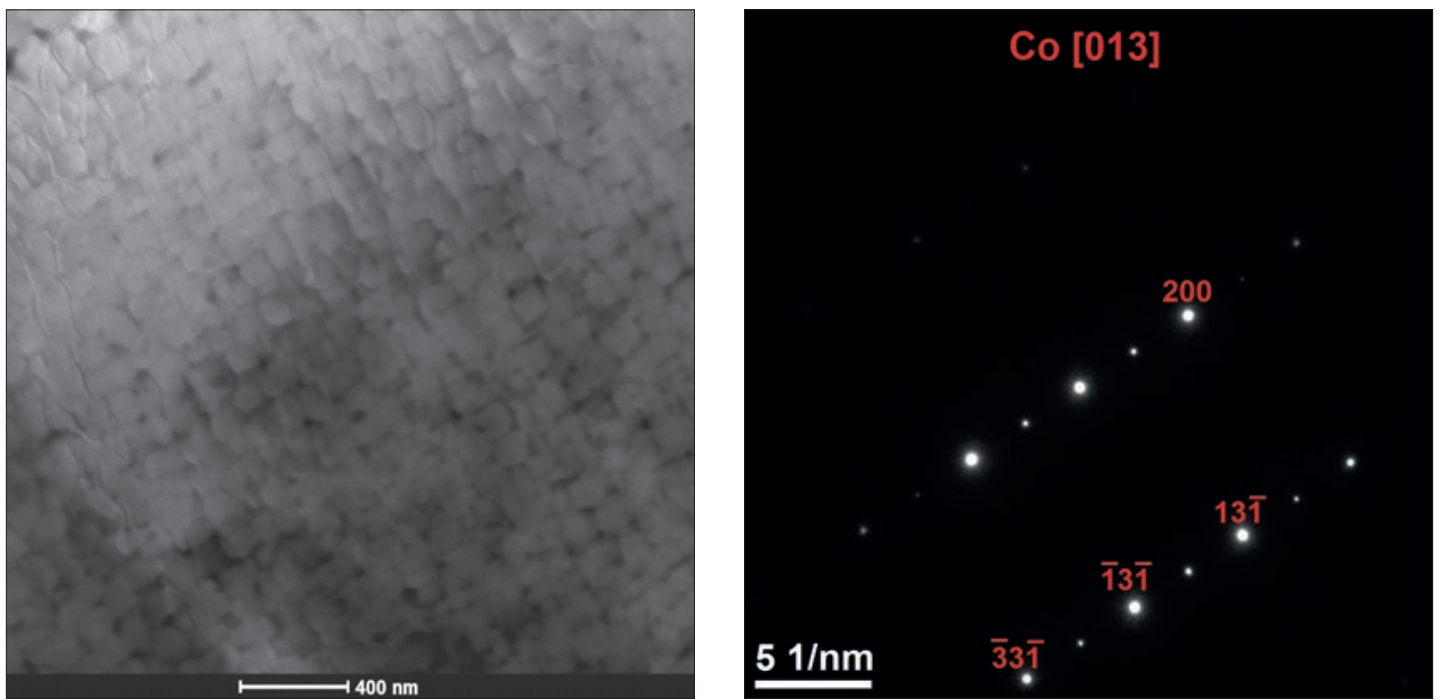

Fig. 5. Microstructure of the Co-20Ni-10Al-5Mo-2Nb superalloy matrix observed using an S/TEM microscope with selective electron diffraction from the presented area

Rys. 5. Obraz mikrostruktury osnowy nadstopu Co-20Ni-10Al-5Mo-2Nb zaobserwowany z wykorzystaniem mikroskopu S/TEM wraz z selektywną dyfrakcją elektronową z przedstawionego obszaru

firmed by selective electron diffraction (Fig. 5). Precipitates of probably the primary $\mathrm{L}_{2}$ phase, with the formula $\mathrm{Co}_{3}(\mathrm{Al}$, $\mathrm{Mo}, \mathrm{Nb})$, as well as areas rich in niobium, favouring the precipitation of the $\mathrm{Co}_{3}(\mathrm{Al}, \mathrm{Mo}, \mathrm{Nb})$ phase, were also observed.

\section{CONCLUSIONS}

The analysis of the primary microstructure of the Co-20Ni-10Al-5Mo-2Nb alloy showed that the solidification process in graphite forms had a strong influence on the segregation of alloying elements. The greatest tendency to interdendritic segregation was found in the case of the niobium addition, while much lower in the case of molybdenum. The probable formation of the $\mathrm{Co}_{3} \mathrm{Nb}$ and $\mathrm{Co}_{3} \mathrm{Mo}$ phases was observed in the interdendritic zone, as well as $\mathrm{Coss} / \mathrm{Co}_{3}(\mathrm{Al}, \mathrm{Mo}, \mathrm{Nb})$ eutectic structures. The structural components are characterised by a different morphology. The formation of these structural elements causes the depletion of the solution in niobium and molybdenum in their immediate vicinity and a reduction in the tendency for the formation of the primary $\mathrm{Co}_{3}$ phase (Al, Mo, $\mathrm{Nb}$ ). The dendrite core areas that are rich in $\mathrm{Mo}$ and $\mathrm{Nb}$ (in solid solution) showed a much stronger tendency to form the primary $\mathrm{Co}_{3}(\mathrm{Al}, \mathrm{Mo}, \mathrm{Nb})$ phase in a spherical/cuboidal form.

\section{REFERENCES}

[1] B. Mikołowski. Stopy żaroodporne i żarowytrzymałe - nadstopy. Kraków: AGH Press, 1997.

[2] S.K. Makineni, B. Nithin, K. Chattopadhyay. A new tungsten-free $\gamma / \gamma$ ' Co-Al-Mo-Nb-based superalloy. Scripta Materialia 2015, 98, p. 36-39.

[3] C.S. Lee. Precipitation-Hardening Characteristics of Ternary Cobalt Aluminum - X Alloys. The University of Arizona, 1971.

[4] J. Sato, T. Omori, K. Oikawa, I. Ohnuma, R. Kainuma, K. Ishida. Cobalt-base high-temperature alloys. Science, 2006, 312 (5770), p. 90-91.

[5] C.H. Zenk, S. Neumeier, H.J. Stone, M. Goken. Mechanical properties and lattice misfit of $\gamma / \gamma^{\prime}$ strengthened Co-base superalloys in the Co-W-Al-Ti quaternary system. Intermetallics, 2014, 55, p. 28-39.

[6] S.K. Makineni, B. Nithin, K. Chattopadhyay. Synthesis of a new tungsten-free $\gamma / \gamma$ ' cobalt-based superalloy by tuning alloying additions. Acta Materialia 2015, 85, p. 85-94.

[7] S.K. Makineni, B. Nithin, D. Palanisamy, K. Chattopadhyay. Phase evolution and crystallography of precipitates during decomposition of new "tungsten- free" $\mathrm{Co}(\mathrm{Ni})-\mathrm{Mo}-\mathrm{Al}-\mathrm{Nb} \gamma / \gamma$ ' superalloys at elevated temperatures. J. Mater. Sci., 2016, 51 (17), p. 7843-7860.
[8] D. Migas, G. Moskal, D. Niemiec. Surface condition of new $\gamma-\gamma^{\prime}$ Co-Al-Mo-Nb and Co-Al-W cobalt-based superalloys after oxidation at $800^{\circ} \mathrm{C}$. J. of Materials Engineering and Performance, 2018, 27 (2), p. 447-456.

[9] A. Tomaszewska, G. Moskal, T. Mikuszewski, G. Junak, A. Płachta. Primary Microstructure Characterization of As-Casted Co-20Ni7Al-7W Superalloy. Arch. Foundry Eng. 2019, 19 (3), p. 78-73.

[10] D. Migas, M. Kierat, G. Moskal. The oxide scales formed on different co-ni based superalloys during isothermal oxidation at 800 and $900^{\circ}$ C. Arch. Metall. Mater. 2021, 66 (1), p. 5-14.

[11] Q. Liu, J. Coakley, D.N. Seidman, D.C. Dunand. Precipitate evolution and creep behavior of a W-free Co-based superalloy. Metall. Mater. Trans. A, 2016, 47 (12), p. 6090-6096.

[12] L. Fernando, R. Tirado, S. Taylor, D.C. Dunand. Effect of Al, Ti and $\mathrm{Cr}$ additions on the $\gamma-\gamma$ ' microstructure of W-free Co-Ta-V-Based superalloys. Acta Materialia, 2019, 172, p. 44-54.

[13] B. Lux, W. Bollmann. On the mechanism of carbide precipitation in cobalt base alloy 509. Cobalt, 1969, 42, p. 3-13. 